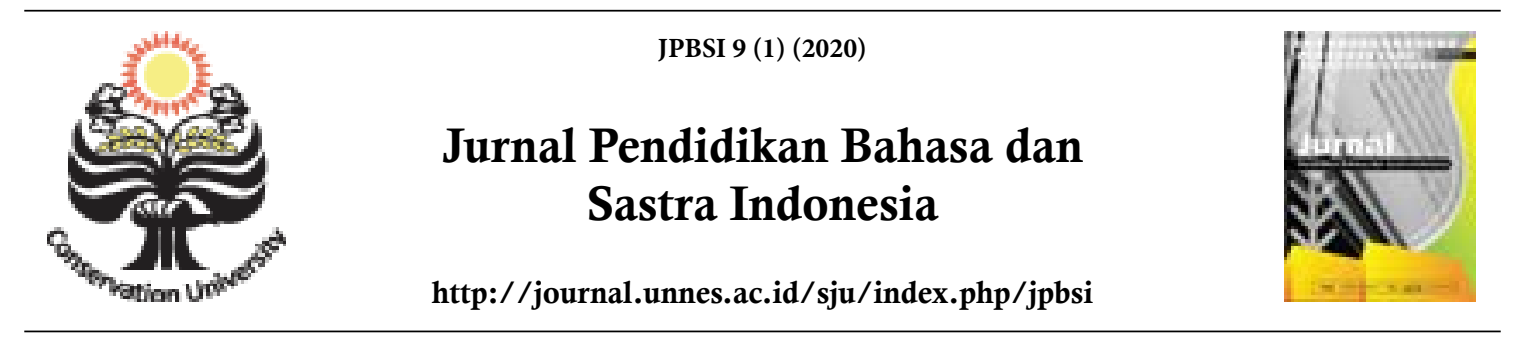

\title{
MODEL PENILAIAN PRODUKTIF MATA KULIAH MENULIS BERBASIS NILAI HUMANIS
}

\author{
Fahrudin Eko Hardiyanto \\ Pendidikan Bahasa dan Sastra Indonesia, Fakultas Keguruan dan Ilmu Pendidikan, \\ Universitas Pekalongan, Indonesia
}

\section{Info Artikel}

Sejarah Artikel:

Diterima Maret 2020

Disetujui April 2020

Dipublikasikan Mei 2020

Keywords:

assessment, productive,

writing, human values.

\begin{abstract}
Abstrak
Penelitian ini bertujuan untuk mendeskripsikan model-model penilaian produktif kompetensi menulis berbasis nilai humanis. Penilaian dalam pembelajaran menulis merupakan hal yang strategis dan menentukan keberhasilan dalam pencapaian tujuan pendidikan. Penilaian sering dianggap sebagai salah satu dari tiga pilar utama yang sangat menentukan kegiatan pembelajaran. Ketiga pilar tersebut adalah perencanaan, pelaksanaan dan penilaian. Rumusan masalah pada penelitian ini adalah bagaimanakah penilaian unjuk kerja pada mata kuliah menulis berbasis nilai-nilai humanis? Bentuk-bentuk penugasan yang dapat dijadikan penilaian dan proses pembelajaran mata kuliah menulis dengan berbasis pada nilai-nilai humanis yaitu 1) Praktik Menulis Makalah, 2) Praktik Menulis Artikel Populer; 3) Praktik Menulis Otobiografi; 4) Praktik Menulis Berita; 5) Praktik Menulis, Menyusun, dan Pameran Majalah Dinding; 6) Praktik Menulis Buletin; dan 7) Praktik Menulis Proposal Kegiatan Sosial.
\end{abstract}

\begin{abstract}
This study aims to describe the productive assessment models of writing competency based on humanist values. Assessment in learning to write is a strategic thing and determines success in achieving educational goals. Assessment is often regarded as one of the three main pillars that determine learning activities. The three pillars are planning, implementation and evaluation. The formulation of the problem in this research is how is the performance evaluation on the writing subject based on humanist values? Forms of assignment that can be used as an assessment and learning process of writing courses based on human values are 1) Paper Writing Practices, 2) Popular Article Writing Practices; 3) Autobiographical Writing Practices; 4) News Writing Practices; 5) Writing, Compiling, and Exhibition Magazine Wall Practices; 6) Practice of Writing Bulletins; and 7) Practice of Writing Social Activity Proposals.
\end{abstract}




\section{PENDAHULUAN}

Pendidikan pada hakikatnya adalah membangun karakter kompeten pada diri seseorang. Dari yang belum belum cakap menjadi cakap, dan mengubah dari yang belum baik menjadi baik. Perubahan tersebut dapat berupa kepribadian atau perilaku karakter seseorang ataupun perubahan kompetensi dan kecakapan tertentu.

Dalam pembelajaran sebuah penilaian merupakan bagian yang tidak dapat dipisahkan dari proses pembelajaran. Penilaian sering dianggap sebagai salah satu dari tiga pilar utama yang sangat menentukan kegiatan pembelajaran. Ketiga pilar tersebut adalah perencanaan, pelaksanaan dan penilaian. Penilaian merupakan suatu proses berkelanjutan tentang pengumpulan dan penafsiran informasi untuk menilai keputusankeputusan yang dibuat dalam rancang suatu sistem pengajaran. Rumusan ini memiliki tiga implikasi: pertama, evaluasi ialah suatu proses yang terus-menerus, bukan hanya pada akhir pengajaran tetapi dimulai sebelum dilaksanakannya pengajaran sampai dengan berakhirnya pengajaran. Kedua, proses evaluasi senantiasa diarahkan ke tujuan tertentu, yaitu untuk mendapatkan jawaban tentang bagaimana memperbaiki pengajaran. Ketiga, evaluasi menuntut penggunaan alat-alat ukur yang akurat dan bermakna untuk mengumpulkan informasi yang dibutuhkan guna membuat keputusan (Hamalik, 2008:210).

Salah satu pilar dari tujuan pendidikan adalah menumbuhkan sikap, etika, dan kepribadian unggul peserta didik melalui serangkaian upaya pendidikan terencana. Kepribadian unggul merupakan wujud dari indikator keberhasilan pendidikan. Jika pendidikan hanya mampu melahirkan peserta didik yang cerdas secara intelektual namun kurang memprihatinkan secara moral, berarti pendidikan belum melahirkan kontribusi.

Hardiyanto (2011:3) mengemukakan bahwa satu kontribusi pendidikan adalah membangun kebudayaan. Budaya dan tradisi kehidupan yang penuh makna, manfaat, dan bermartabat. Makna pendidikan yang mampu memberi arah kemajuan sebuah bangsa dari seorang manusia. Memilah dan memilih secara selektif nilai kehidupan yang baik dari berbagai residu. Selain itu, pendidikan haruslah membawa dampak manfaat yang luas bagi masyarakat dunia. Pendidikan mempunyai peran strategis sebagai sarana human resources dan human investment. Artinya, pendidikan selain bertujuan menumbuhkembangkan kehidupan yang lebih baik, juga telah ikut mewarnai dan menjadi landasan moral dan etika dalam proses pemberdayaan jati diri bangsa.
Guna membangun pemberdayaan kompetensi mahasiswa dalam bidang menulims dibutuhkan sosok dosen tang mampu memberikan arah penilaian baik proses maupun hasil pembelajaran menulis.

Pembelajaran kompetensi menulis bagi mahasiswa merupakan sebuah keniscayaan untuk membekali mahasiswa menjadi pribadi cakap dan unggul terutama dalam komunikasi tulis. Namun demikian pada kenyataannya pembelajaran menulis menuai banyak kendala, baik dari mahasiwa maupun dosen itu sendiri. Beberapa problema dalam pembelajaran menulis yakni persepsi di kalangan mahasiswa dan dosen yang menyatakan bahwa kemampuan menulis sudah menjadi bakat bawaan sejak lahir. Padahal kemampuan menulis tidak diperoleh secara alamiah, tetapi melalui proses belajar mengajar secara terus menerus.

Pada dasarnya setiap orang memiliki kemampuan dalam menulis sebagai salah satu aspek keterampilan berbahasa. Kemampuan itu diperolehnya melalui proses pembelajaran bukan warisan. Dalam status apapun kemampuan menulis sangat diperlukan, lebih - lebih sebagai seorang dosen, guru atau mahasiswa. Melalui menulis, ide dan gagasan dapat diungkapkan dengan lebih mudah (Widhiyanto, 2019:55) Permasalahan yang dihadapi para penulis pemula antara lain memiliki kecanggungan untuk mulai berproses. Selain itu, kemampuan mengenai pengorganisasian tulisan atau karya juga menjadi pertimbangan untuk tidak segera mulai berproses.

Keberhasilan terhadap proses pembelajaran menulis dapat dipantau dan dikawal prosesnya melalui adanya penilaian yang sesunguhnya terhadap kompetensi yang dibangun pada mata kuliah menulis ini. Penilaian belajar bukan hanya bersifat kognitif saja, tetapi juga mencakup semua potensi yang ada pada mahasiswa. Keberhasilan program perkuliahan selalu dilihat dari aspek hasil belajar, sementara program pembelajaran yang bersifat unjuk kerja (performance) jarang dilakukan secara serius sehingga bisa lebih produktif. Menurut Setyono (2005:3) penilaian unjuk kerja (performance assessment) adalah penilaian berdasarkan hasil pengamatan penilai terhadap aktivitas mahasiswa sebagaimana yang terjadi.

Berdasarkan uraian tersebut diketahui bahwa penilaian produktif pada kompetensi menulis memiliki nilai strategis sebagai bahan evaluasi dalam pembelajaran. Penilaian produktif pada kompetensi menulis dengan pendekatan nilainilai humanis merupakan penelitian sekaligus pengembangan terhadap penilaian kompetensi 
menulis. Penilaian yang dilakukan pada penelitian ini memiliki kebaruan yakni penilian menulis berbasis nilai humanis.

\section{METODE}

Penelitian ini adalah penelitian pengembangan atau Research and Development (R\&D). Penelitian pengembangan model penilaian produktif kompetensi menulis berbasis nilai humanis. Penelitian ini dilaksanakan di Program studi Pendidikan Bahasa dan Sastra Indonesia FKIP Universitas Pekalongan. Data penelitian ini adalah komponen kegiatan perkuliahan pada mata kuliah menulis. Penelitian berupa Educational Research and Development atau R \& D (Borg \& Gall, 1989).

Program yang dikembangkan berupa model penilaian produktif berbasis nilai humanis. Adapun alur penelitian $\mathrm{R} \& \mathrm{D}$ secara rinci diawali dengan kegiatan studi pustaka lalu diteruskan dengan studi lapangan untuk melihat pola pembelajaran yang diterapkan selama ini oleh dosen. Setelah melakukan analisis temukan, berikutnya peneliti mendesain model pembelajaran yang akan dicobakan. Desain model diujicobakan ke sampel terbatas yang ditetapkan, lalu dievaluasi dan diperbaiki bila masih terdapat kelemahan. Hasil evaluasi dan perbaikan tersebut dijadikan sebagai model penilaian produktif. Model ini diterapkan dalam pembelajaran di kelas sebagai pemberlakuan tahap pertama lalu dievaluasi den disempurnakan bila dipandanng masih terdapat kekurangan atau kelemahan yang masih terdapat kekurangan atau kelemahan yang masih muncul, berikutnya diterapkan kembali dalam pembelajaran di kelas sebagai pemberlakuan tahap kedua, lalu dievaluasi dan disempurnakan kembali bila masih terdapat kelemahan. Demikian seterusnya sampai penelitian tersebut mendapatkan hasil yang diharapakan.

Data penelitian ini akan dikumpulkan melalui penulisan makalah dan observasi kegiatan mahasiswa di kelas selama proses pembelajaran berlangsung. Data tentang tanggapan mahasiswa diambil dari penyebaran angket kepada mahasiswa. Penyebaran angket dilakukan diawal pembelajaran, hal ini dilakukan agar menemukan permasalahan tetntang tahapan menulis, tata tulis karya ilmiah dan penilaian makalah dari dosen, yang peneliti jadikan rancangan model pengembangan penilaian keterampilan menulis dengan berbasis nilai humanis.

\section{HASIL DAN PEMBAHASAN}

Salah satu persoalan sosial yang sering muncul dalam kehidupan interaksi sosial yakni ujaran kebencian yang terdapat pada sebuah tulisan seseorang. Ujaran kebencian (hate speech) dipahami sebagai tindak tutur (baik lisan maupun tulisan) yang dilakukan oleh sesorang dalam bentuk hasutan, hinaan, atau pernyataan yang bernada provokasi kepada individu atau kelompok yang lain dalam berbagai aspek seperti agama, ras, etnis, kewarganegaraan, gender, disabilitas, dan lain-lain. Fenomena ujaran kebencian pada umumnya menunjukkan betapa persoalan penggunaan bahasa mempengaruhi situasi kehidupan sosial sebuah masyarakat.

Bahasa dan penggunaannya mampu mendorong perubahan dan memberi warna dalam kehidupan. Pada sisi inilah bahasa dibutuhkan oleh semua bidang kehidupan untuk berbagai maksud, tujuan, dan kepentingan. Penggunaan bahasa yang mampu menumbuhkan kebaikan akan dapat membawa ke arah perubahan dan tata kehidupan yang beradab dan tercerahkan. Sebaliknya, penggunaan bahasa yang kasar (sarkastik), merusak nilai-nilai (destruktif), dan memprovokasi orang lain/masyarakat (provokatif), akan melahirkan disharmoni dan persoalan sosial yang dapat merusak tatanan kehidupan.

Menurut Sutiyono (2000:4) salah satu obat penawar yang diharapkan dapat mengatasi persoalan kekerasan di Indonesia adalah pendidikan. Artinya, guna membentuk sesorang berkarakter baik, perlu ada rekayasa sosial yang diwujudkan melalui proses pendidikan. Tentu saja diharapkan dapat mewujudkan generasi muda (mahasiswa) yang berkarakter. Dalam suatu karakter bangsa yang baik tercermin peran bangsa yang amat penting dan menentukan. Bangsa yang memiliki karakter keropos sulit untuk bisa maju. Dapat dinyatakan bahwa karakter merupakan segalagalanya bagi kemajuan suatu bangsa. Oleh karena itu, untuk menuju pada perwujudan karakter yang baik serta menjauhkan perilaku kekerasan setidak-tidaknya harus diproses melalui pendidikan. Salah satu cara memperkuat karakter adalah pembelajaran yang dilaksanakan dengan nilainilai humanis (Subyantoro, 2019).

Penilaian kompetensi menulis bagi mahasiswa berbasis nilai humanis dilaksanakan dalam pembelajaran dengan sistematika rancangan, pelaksanaan, dan penilaian sebagai berikut.

\section{Deskripsi Mata Kuliah Retorika}

Merujuk pada kurikulum pada Prodi Pendidikan Bahasa dan Sastra Indonesia Universitas Pekalongan bahwa mata kuliah menulis bertujuan untuk meningkatkan kompetensi mahasiswa dalam berkomunikasi di tengah-tengah masyarakat melalui kegitan menulis. Bahan pembelajaran 
meliputi teori menulis dan praktik. Pokok bahasan yang diberikan meliputi hakikat menulis sebagai proses komunikasi, ragam tulisan meliputi artikel, makalah, proposal,majalah dinding, dan buletin.

Kegiatan perkuliahan dilaksanakan melalui pembelajaran tatap muka, latihan, dan penugasan. Penilaian perkuliahan terutama dilakukan melalui pendekatan proses terhadap latihan dan penugasan praktik menulis dengan menanamkan nilai-nilai humanis.

\section{Kriteria Penilaian Unjuk Kerja}

Dengan mengacu pada kurikulum tersebut, pembelajaran mata kuliah retorika lebih banyak berbasis praktik atau dalam penilaian menggunakan penilaian unjuk kerja (performance assessment). Jenis penilaian unjuk kerja ini mengacu pada kriteria penilaian yakni sebagai berikut.

a.)Penilaian kinerja digunakan untuk menilai kemampuan siswa melalui penugasan (task). Dalam menilai kinerja siswa tersebut, perlu disusun kriteria. Kriteria yang menyeluruh disebut rubrik. Dengan demikian wujud penilaian kinerja yang utama adalah penugasan yang mengikuti kriteria penilaian. Tugas-tugas kinerja digunakan untuk memperlihatkan kemampuan siswa dalam melakukan suatu keterampilan tentang sesuatu dalam bentuk nyata. Selanjutnya rubrik digunakan untuk memberikan keterangan tentang hasil yang diperoleh siswa (Zainul, 2001:9-11)

b.) Ada beberapa kriteria yang dapat digunakan sebagai bahan pertimbangan dalam penilaian kinerja antara lain: generalizability atau keumuman, authenticity atau keaslian/nyata, muliple focus (lebih dari satu fokus), fairness (keadilan), teachability (bisa tidaknya diajarkan), feasibility (kepraktisan), Scorability atau bisa tidaknya tugas tersebut diberi skor (Popham, 1995:147).

\section{Bentuk-Bentuk Penugasan}

Merujuk pada tujuan mata kuliah menulis bahwa mahasiswa diharapkan setelah mengikuti mata kuliah ini dapat dengan cakap menggunakan bahasa Indonesia untuk berbagai kebutuhan dalam berkomunikasi tulis di tengah-tengah masyarakat, maka penugasan sebagai proses perkuliahan dan sekaligus sebagai penilaian pembelajaran lebih banyak berupa unjuk kerja mahasiswa. Bentuk-bentuk penugasan yang dapat dijadikan penilaian dan proses pembelajaran yaitu sebagai berikut.

1) Praktik Menulis Makalah

2) Praktik Menulis Artikel Populer
3) Praktik Menulis Otobiografi

4) Praktik Menulis Berita

5) Praktik Menulis, Menyusun, dan Pameran Majalah Dinding

6) Praktik Menulis Buletin

7) Praktik Menulis Proposal Kegiatan Sosial

Bentuk-bentuk penilaian pembelajaran retorika tersebut merupakan khazanah modelmodel penilaian yang dapat diaplikasikan dalam pendidikan karakter diri dan kompetensi kebahasaan mahasiswa pada aspek menulis. Penilaian pembelajaran hakikatnya adalah proses penguatan pendidikan nilai kebaikan, bukan sekadar memberikan simpulan hasil akhir terhadap kemampuan seseorang. Penilaian adalah bagian dari pendidikan karakter. Pendidikan karakter merupakan proses panjang pembentukan mentalitas, moralitas, etika, kepribadian, kebiasaan, dan nilai-nilai kehidupan yang bisa dipengaruhi dari banyak arah dan cara, salah satunya dengan pendekatan keagaamaan.

\section{Nilai Humanis}

Humanisasi berarti menebar kebaikan dengan titik pijak keadilan. Misi humanisasi adalah menempatkan manusia sebagai pemimpin di muka bumi, yang mesti menjalankan misi keadilan. Dalam konteks perkuliahan, dosen dalam mengelola pembelajaran dan pendidikan harus mampu menjadi pribadi yang dialogis, ramah, penuh dedikasi, integritas, dan penuh cinta dan kasih sayang.

Humanisme dipandang sebagai sebuah gagasan positif oleh kebanyakan orang. Humanisme mengingatkan kita akan gagasan-gagasan seperti kecintaan akan peri kemanusiaan, perdamaian, dan persaudaraan. Pendidikan humanis sebagai pemikiran pendidikan telah berkembang dengan mengadopsi prinsip-prinsip pendidikan dari dua aliran, yaitu progresivisme dan eksistensialisme. Tetapi pendidikan humanis juga memperoleh dukungan dari para ahli psikologi humanistik dan ahli pendidikan kritis. Prinsip-prinsip pendidikan humanis yang diambil dari prinsip progresivisme adalah prinsip pendidikan yang berpusat pada mahasiswa (child centered), peran dosen yang tidak otoriter, fokus pada keterlibatan dan aktivitas mahasiswa, dan aspek pendidikan yang demokratis serta kooperatif. Prinsip-prinsip pendidikan ini adalah sebagai reaksi terhadap pendidikan tradisional yang menekankan pada 
metode pengajaran formal yang kurang memberi kebebasan pada mahasiswa sehingga mahasiswa menjadi tidak kreatif yang sekadar mengikuti program pendidikan yang ditetapkan oleh orang dewasa (Barnadib, 1996:29).

Penanaman nilai-nilai (internalisasi nilai) humanis dalam pembelajaran dan penilaian menulis diwujudkan dalam karya tulis yang dihasilkan oleh mahasiswa mengandung etos humanis, yakni tulisan yang edukatif, santun, mencerahkan pemikiran wawasan pembaca, mengedepankan kebenaran (al haq) bukan tulisan hoak, menghargai kemanusiaan, tidak destruktif dan dapat merugikan orang lain. Karya tulis yang dihasilkan mahasiswa dinilai dari aspek-aspek humanis tersebut. Dengan demikian ini dapat pula menjadi pembiasaan pembangunan karakter baik pada diri mahasiswa dan juga dosen dalam ranah pendidikan.

Langkah pembelajaran menulis dengan pendekatan nilai-nilai humanis dilakukan yakni sebagai berikut. 1) Dosen mengenali permasalahan dalam menulis makalah dengan menyebarkan angket; 2) Dosen merancang pembelajaran dari permasalahan yang dikenali; 3) Dosen menerapkan model pembelajaran menulis berbasis nilai humanis yang telah dirancang; 4) Dosen melakukan perbaikan dari kekurangan uji coba I; 5) Dosen melakukan penilaian menulis dari uji coba II; 6) Dosen melakukan perbaikan dari uji coba II; 7) Dosen melakukan penilian uji coba III; 8) Hasil dari ketiga uji coba yang dilakukan dianalisis dan dilakukan pengolahan data sesuai dengan tahapan metode R\&D; 9) Dosen menemukan pengembangan model dari keterampilan menulis berbasis nilai humanis; dan 10) Pengembangan model penilaian produktif menulis berbasis nilai-nilai humanis.

\section{SIMPULAN}

Penilaian produktif berbasis nilai humanis merupakan penilaian yang dapat mengungkapkan kemampuan mahasiswa dalam pemahaman konsep, pemecahan masalah dan komunikasi tuis melalui berbagai ragam penilaian unjuk kerja produktif. Ini merupakan penilaian tindakan atau tes praktik yang secara efektif dapat digunakan untuk kepentingan pengumpulan berbagai informasi tentang bentuk-bentuk perilaku atau keterampilan yang diharapkan muncul dalam diri mahasiswa.

Bentuk-bentuk penugasan dan penilaian produktif yang dapat dijadikan penilaian dan proses pembelajaran mata kuliah menulis yaitu 1) Praktik Menulis Makalah, 2) Praktik Menulis Artikel Populer; 3) Praktik Menulis Otobiografi;
4) Praktik Menulis Berita; 5) Praktik Menulis, Menyusun, dan Pameran Majalah Dinding; 6) Praktik Menulis Buletin; dan 7) Praktik Menulis Proposal Kegiatan Sosial. Betuk-bentuk penilaian tersebut diimplementasikan melalui pembelajaran menulis berbasis nilai-nilai humanis dalam produksi karya.

\section{REFERENSI}

Arikunto, Suharsimi. 1993. Evaluasi pendidikan. Jakarta : Rineka cipta.

Barnadib, Imam, 1996. Filsafat Pendidikan Islam, Yogyakarta: Andi offcet.

Borg, W.R. dan Gall, M.D. 1989. Educational Research: An Introduction, Fifthy Edition. New York: Longman.

Hamalik, Oemar. 2008. Perencanaan Pengajaran Berdasarkan Pendekatan Sistem. Jakarta:Bumi Aksara.

Hardiyanto. Fahrudin Eko. 2011. "Nilai-Nilai Kesantunan Berbicara dalam Al-Quran sebagai Penguatan Pendidikan Karakter bagi Pelajar di Sekolah (Kajian Religiupragmatik). Makalah. Universitas Pekalongan.

Majid, A. 2006. Perencanaan Pembelajaran Mengembangkan Standar Kompetensi Guru. Bandung: Remaja Rosdakarya.

Muslich, Masnur, (2007) KTSP Pembelajaran Berbasis Kompetensi dan Kontekstual. Jakarta: PT. Bumi Angkasa.

Popham, W. 1995. Classroom Assessment. Boston: Allyn and Bacon.

Setyono, Budi.2005. Penilaian Otentik dalam Kurikulum Berbasis Kompetensi (dalam jurnal pengembangan pendidikan). Lembaga Pembinaan dan Pengembangan Pendidikan (LP3) Universitas Jember.

Subyantoro, H., dan Siroj, M. B. 2019. Strengthening Maritime Culture with Humanistic Value in Enrichment Books of Bahasa Indonesia. KnE Social Sciences, 614-626.

Sutiyono. 2000. Nilai-Nilai Humanisme Dalam Proses Pembelajaran Seni Tari. Jurusan Pendidikan Seni Tari FBS Universitas Negeri Yogyakarta.

Widhiyanto, R dan Muhammad Badrus S. 2019. Yuk! Belajar Menulis Teks Eksposisi Bermuatan Multikultural. Semarang: Cipta Prima Nusantara.

Zainul, Asmawi. 2001. Alternative Assessment. Jakarta: Universitas Terbuka. 